\title{
東京芝浦電氣株式会社 鶴見研究所
}

わが國における民間研究所として 歷史が最も古く, 多くの業績をもつ 東京芝浦電氣の研究所は, 軽電関倸 のマッダ研究所および重電関係の鶴 見研究所乞から成っている。この內 鶴見研究所はマッダ研究所の創始 (1899 年) よりやや遅れ, 1906 年 (明 治 39 年）に, 東芝の前身たる旧芝 浦製作所（株）の芝浦工場の一隅 で, 絕緣油や碍子などの試驗研究を 行ら小規模な研究室として発足した が, その後会社の発展, 事業の拡張 とともに漸次規模も大きくなり, 現 在では鶴見工場敷地內に，写自に見 られる研究所本館をはじめとする 19 棟延べ約 4000 坪の建物に, 電氣 工学, 機械工学, 物理, 化学, 冶金, 案業など多方面の專門家を含む約 300 名の所員を擁する大研究所にな っている。全体は材料部, 機器部沶 よびシリコーン部の 3 部, 1 室 9 課 より成り，重電機器に関する製品， 所要材料の改良開発, 研究成果を生 產化するに必要な試作研究, ならび に工場および電力施設現物などにお いて発生する技術上の諸問題解決の ための調查研究を任務としている。

この內化学関係の部門は, 材料部 の絕緣研究課, 化学試作課拉よびシ リコーン部がある。

絕緣研究課は, 主として電機器の 絕線材料, 整料などの研究を行って 打り,また各種化学分析を担当して いる。最近のテーマには, 耐熱性ワニ ス一ーイソシアネート系ワニス, シ リコーン・アルキッドワニスなどの 開発, エポキシ樹脂の応用一一接着, 埋达用および塗料など, ポリエステ ル樹脂の応用などがあり，また粉末 マイカを基材とするマイカ紙および マイカナイト (マイカマット) など もすでに実用化の段階に大ってい る。また絕緣物の劣化の問題, 耐熱 性の向上してきたマグネットワイヤ の耐熱壽命の評価なども最近の研究 の対象である。

分析には Beckmann の分光分析 器, Polarograph などの新銳設備 も活用されている。

化学試作課は, 研究の結果なる絕

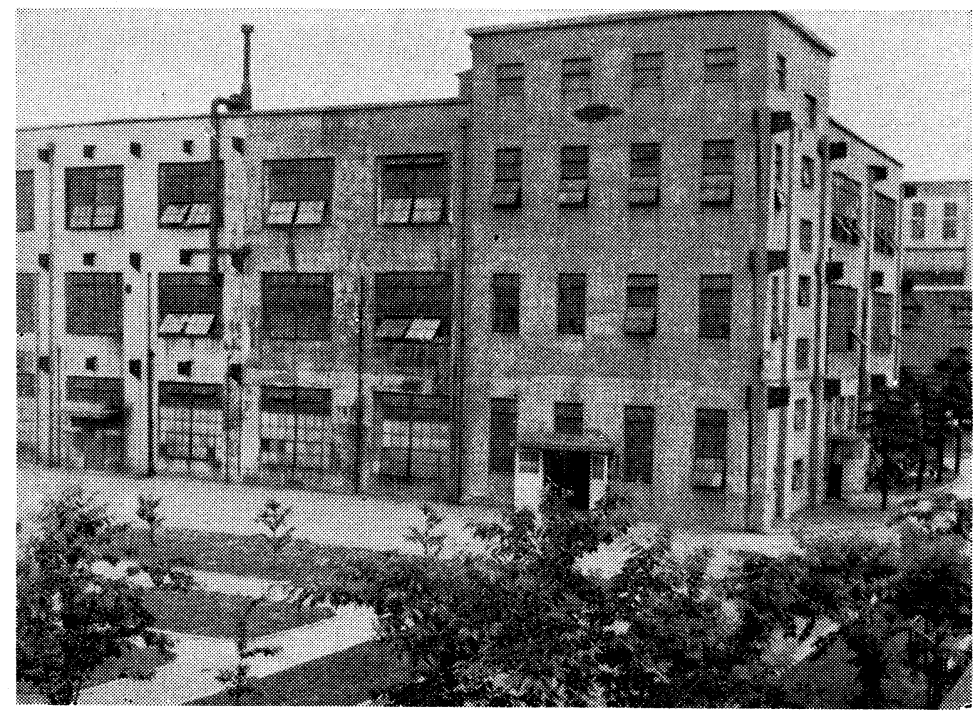

鶴見研究所本 館

線ワニス，塗料類のパイロットプラ ントとしての製造研究を行ってお り，またマイカレックスの材料およ び製造方法の研究, 避雷器要素であ る非直線性抵抗体レジスト・バルブ 円板の燒成研究などを行っている。

シリコーン部は比較的新しく, 部 として独立した研究部門であるが, その研究歷は古く, 戰時中に耐篹性 絕緣塗料を得べく研究中, シリコー ン化合物に関する米國情報を入れ て, 早速研究に着手したのが昭和 16 年夏のことであった。その後过余曲 折はあったが，昭和 25 年には，パ イロットプラントの建設を見るに至 り, 同 28 年には, ワニス工場を主 とした本格的生產工場が完成した。 ついで通產省よりの工業化試剑研究 補助金を受けて, 29 年春シリコー ン・ラバーの工業的製造法の研究を 完成し，ここに全シリコーン製品の 生產態勢が確立したのである。

シリコーン部は, 基礎研究と製造 の二部門に分れ，これから表裏一体 となって, 新品種の開発, 品質の改 良に努力している。

研究部門は, 原料であるクロロシ ランの研究をはじめ, ワニス, オイ ル，ラバー，撥水剈およびオイルの
加工製品に関する基礎研究と応用研 究とを担当する研究室に分れてお り, 各種シリコーンの絕緣特性, シ リコーンによる絕緣方式, 絕緣処理 法などの研究は, 絕緣研究課と緊密 な連絡の下に行っている。

製造部門は，シリコーン各製品 40 余種を生產しており, 工業材料界 に少なからず貢献している。

（橫浜市鶴見区未広町 2 丁目 4 番地）

\section{海外文献の紹介誌}

\section{高分子交献集} 月刊・B 5 版

購読会費 $\left(\begin{array}{lr}1 \text { 力年 } & 1,600 \text { 円 } \\ \text { 牛力年 } & 800 \text { 円 }\end{array}\right)$

瀻維・プラスチックス・ ヨ゙ム・叙 料・その他

睡読御希望の方は学会事務局宛 御申し込み下さい。

高分子学会 